\title{
Reaction of melon genotypes to Meloidogyne incognita and Meloidogyne javanica ${ }^{1}$
}

\author{
Guilherme Matos Martins Diniz², Willame dos Santos Candido², Renato Silva Soares², \\ Lucas da Silva Santos ${ }^{2}$, Marcus Vinícius Marín², Pedro Luiz Martins Soares², Leila Trevisan Braz ${ }^{2}$
}

\section{ABSTRACT}

Melon is one of the most economically important crops cultivated in Brazil, especially in the Northeast region. However, as its cultivation increases, phytosanitary problems arise, including those caused by nematodes, which are most effectively controlled using resistant cultivars. This study aimed at assessing the reaction of muskmelon genotypes, in terms of resistance to Meloidogyne incognita and $M$. javanica infestation. The experiment was conducted under greenhouse conditions using a completely randomized design, in a $2 \times 15$ factorial scheme, with six replications. A total of 15 muskmelon genotypes were evaluated and the 'Santa Cruz Kada' tomato was used as a susceptible control. The total number of eggs and juvenile nematodes in the roots and the reproduction factor were used to assess the genotype reaction. None of the genotypes was resistant to $M$. incognita. Eight genotypes were classified as resistant to $M$. javanica and promising for use in melon breeding programs.

KEY-WORDS: Cucumis melo L.; plant breeding; root-knot nematodes.

Melon (Cucumis melo L.) is one of the most economically important crops in Brazil, especially in the Northeast region, where favorable climatic conditions allow it to be grown year-round (Pires et al. 2013).

China is the world's leading producer of muskmelon, with an annual average of 17.5 million tons (FAO 2012). Brazil is ranked tenth, with an estimated production of 565.9 thousand tons, in 2013, and its Northeast region reaching 537.4 thousand tons (IBGE 2013).

With marked growth in recent years, the cultivation of this cucurbit species has attracted attention. Muskmelon has advantages over other melons, underscoring its good commercial value and profitability. Moreover, it contains a high level

\begin{abstract}
RESUMO
Reação de genótipos de meloeiro a

Meloidogyne incognita e Meloidogyne javanica

O melãoé uma das culturas de grande importância econômica no Brasil, especialmente para o Nordeste. Contudo, à medida que seu cultivo é intensificado, surgem problemas fitossanitários, dentre eles os causados por nematoides, cujo controle tem como medida mais efetiva o uso de cultivares resistentes. Objetivou-se avaliar a reação de genótipos de meloeiro quanto à hospedabilidade de Meloidogyne incognita e $M$. javanica. O ensaio foi conduzido em condições de casa-de-vegetação, utilizando-se delineamento inteiramente casualizado, em esquema fatorial 2 x 15, com seis repetições. Foram avaliados 15 genótipos de meloeiro, e o tomateiro 'Santa Cruz Kada' foi utilizado como padrão de suscetibilidade. Para avaliação da reação dos genótipos, utilizadram-se o número total de ovos e juvenis nas raízes e o fator de reprodução. Nenhum dos genótipos foi resistente a $M$. incognita. Oito genótipos foram classificados como resistentes a $M$. javanica e promissores para emprego em programas de melhoramento genético do meloeiro.
\end{abstract}

PALAVRAS-CHAVE: Cucumis melo L.; melhoramento de plantas; nematoides de galha.

of soluble solids, responsible for its taste and visual aspect, which differentiates it from other types of melon in the market (Rizzo \& Braz 2001). However, the intensive muskmelon cultivation has resulted in a number of phytosanitary problems, particularly the occurrence of root diseases in the main producing areas (Andrade et al. 2005), being the root-knot disease among the most destructive ones.

The Meloidogyne Goeldi genus contains about 90 species described and more than 2,000 plant host species (Karsen \& Moens 2006, Perry et al. 2009), with some of them causing serious damage to cucurbits such as pumpkin, zucchini, squash, cucumber, watermelon and melon (Pinheiro \& Amaro 2010). M. incognita (Kofoid \& White) Chitwood,

1. Manuscript received in Jan./2016 and accepted for publication in Mar./2016 (http://dx.doi.org/10.1590/1983-40632016v4639603).

2. Universidade Estadual Paulista Júlio de Mesquita Filho, Faculdade de Ciências Agrárias e Veterinárias, Jaboticabal, SP, Brazil.

E-mails: guilhermedinizzz@hotmail.com,wsc.agro@yahoo.com.br, renato_2366@hotmail.com, lucasagronomia@hotmail.com, marcusvmarin@gmail.com, pedrolms@fcav.unesp.br, leilatb@fcav.unesp.br. 
M. javanica (Treub) Chitwood and M. arenaria Chitwood are the most commonly occurring species, being, in addition, the most harmful to muskmelon (Pinheiro \& Amaro 2010). These nematodes attack the root system and hinder nutrient absorption and translocation, thereby reducing crops productivity and economic yield (Pinheiro et al. 2013).

Nematodes are difficult to control, since each situation requires a careful analysis of the best method to use (Ferraz 1992). Peixoto et al. (1999) report that preventive measures are the most effective in controlling these phytoparasites. These include crop rotation, use of plants toxic to nematodes, soil solarization and application of chemical products. However, the authors state that these measures are laborious, burdensome and often inefficient. The use of resistant plants, therefore, is the most economical and efficient method to control root-knot nematodes in cucurbits, including muskmelon crops (Ito et al. 2014).

In recent years, a number of studies have evaluated sources of resistance to gall-forming nematodes in muskmelon. Santos et al. (1999) studied the resistance of muskmelon genotypes to $M$. incognita and observed that 2 of the 54 genotypes assessed exhibited resistance to the pathogen. Ito et al. (2014) evaluated sources of cucurbit resistance to $M$. incognita and $M$. javanica and found that the 'Gaúcho Redondo' genotype was resistant to $M$. javanica. However, none of the genotypes is resistant to both species.

Therefore, developing muskmelon genotypes with simultaneous resistance to $M$. incognita and $M$. javanica is important for commercial crops, especially for areas where these phytoparasites occur. M. incognita and M. javanica may occur simultaneously. Thus, the present study aimed at assessing the reaction of muskmelon genotypes, in terms of resistance to $M$. incognita and $M$. javanica infestation.

The experiment was conducted from March to June 2015, under greenhouse conditions, in Jaboticabal (21 $1^{\circ} 14^{\prime} 05^{\prime}$ 'S, $48^{\circ} 17^{\prime}$ '09'W and altitude of 614 m), São Paulo State, Brazil, where the average minimum and maximum temperatures were $17^{\circ} \mathrm{C}$ and $27^{\circ} \mathrm{C}$, respectively.

The nematode species used in the study were $M$. javanica and M. incognita. Nematode identification was confirmed in the Nematology Laboratory of the Universidade Estadual Paulista Júlio de Mesquita Filho. The perineal pattern was used according to Taylor \& Netscher (1974) and the morphology of the labial region in males in accordance with Eisenback et al. (1981). After identification, $M$. javanica and $M$. incognita were respectively multiplied in okra (Abelmoschus esculentus L. Moench) and cotton (Gossypium hirsutum L.) susceptible hosts. The seedlings used to multiply the inoculum were maintained in a separate greenhouse. Around 120 days after inoculation, second-stage eggs and juveniles $\left(\mathrm{J}_{2}\right)$ of the nematode species were extracted from the root systems of their respective host plants.

Inocula were prepared using the technique developed by Hussey \& Barker (1973), with changes introduced by Bonetti \& Ferraz (1981) and Oliveira et al. (2009). The population of eggs and juveniles in suspension was estimated using a Peters counting camera, under a photonic force microscope, with subsequent concentration adjustment to 1,000 eggs and $\mathrm{J}_{2} \mathrm{~mL}^{-1}$. Then, 5,000 eggs and the $\mathrm{J}_{2}$ of each species were inoculated by applying $5 \mathrm{~mL}$ of the suspension per plant.

The melon genotypes used were 'AC 29', 'Vendrantais', 'Nantais Oblong', 'PI 124112', 'WMR-29', 'PMR-45', 'PMR-5', 'PMR-6', 'PI 414723', 'Charentais Fom1', 'PI 157082', 'PI 420145', 'PI 482398', 'Louis' and 'Fantasy'. The 'Santa Cruz Kada' tomato was used as a susceptible control for the two nematode species.

The experimental design was completely randomized, in a $2 \times 15$ factorial scheme, with six replications and experimental units of one plant. Muskmelon and tomato seedlings were produced in expanded 128-cell polystyrene trays, in a greenhouse equipped with a sprinkler irrigation system. Two seeds were placed in each cell filled with Bioplant ${ }^{\mathbb{R}}$ substrate, with subsequent thinning to obtain high quality seedlings.

Seedlings were transplanted to plastic pots with $2 \mathrm{~L}$ of previously autoclaved substrate $\left(120^{\circ} \mathrm{C}, 1 \mathrm{~atm}\right.$, 1 hour) when two leaves sprouted, approximately 25 days after sowing. The substrate was composed by a mixture of soil, sand and hardened cow manure $(1: 1: 1)$. During transplanting, the suspension containing eggs and $\mathrm{J}_{2}$ was inoculated separately for each species in the substrate. After 60 days of nematode inoculation, plants were analyzed by separating them into shoots and roots.

To eliminate soil excess, roots were removed from the pots and washed. They were then processed 
to extract eggs and nematodes in other development stages (Hussey \& Barker 1973). The final population of each suspension, derived from the individually processed root systems, was determined by counting eggs and $\mathrm{J}_{2}$ with the aid of a Peters counting camera, under a photonic force microscope. This population was used to determine the reproduction factor $(\mathrm{RF})$, given by the ratio between the initial (IP) and final population $(\mathrm{FP})$ of inoculated eggs $(\mathrm{RF}=\mathrm{FP} / \mathrm{IP})$, where plants with $\mathrm{RF}<1$ were considered resistant to the nematodes and those with $\mathrm{RF} \geq 1$ were considered susceptible to them (Oostenbrink 1966).

The data were log transformed and submitted to analyses of variance for muskmelon genotypes and nematode species and their interaction. Means were compared by the Scott-Knott test $(\mathrm{p}<0.01)$, using the AgroEstat software (Barbosa \& Maldonado Júnior 2010).

There was a significant difference between muskmelon genotypes and nematode species by the F-test, at $1 \%$, which may be an indication of genotype variability for the characteristics assessed (Table 1).

The inoculations performed with $M$. javanica and $M$. incognita were considered efficient, since there was species multiplication in the 'Santa Cruz Kada' tomato, a susceptible host plant for both species. In the tomato plant, the reproduction factor and total number of second-stage eggs and juveniles were respectively 11.7 and 58,457, for $M$. incognita, and 25.8 and 129,057, for M. javanica.

The genotypes assessed exhibited different reactions in relation to the nematode species inoculated. Based on the reproduction factor (RF) of $M$. javanica, according to Oostenbrink (1966), the 'AC 29', 'Nantais Oblong', 'PI 124112', 'PMR-5', 'PMR-6', 'Charentais Fom1', 'PI 157082' and 'PI 420145' genotypes, with RF ranging from 0.2 to 0.8 (Table 1), were classified as resistant. The remaining genotypes studied were classified as susceptible to this species.

Concerning the muskmelon genotypes reaction to $M$. incognita, there was a significant difference between the materials, for the RF variable. Even though genotypes differed, all of them were considered susceptible to $M$. incognita, with RF ranging from 2.52 to 9.22 (Table 1).

Paiva et al. (2004) assessed 30 muskmelon genotypes (Cantaloupe cultivar), selecting eight lines that showed resistance to $M$. incognita. According to

Table 1. Average total number of eggs and $\mathrm{J}_{2}$ and reproduction factor for Meloidogyne javanica and M. incognita in 15 muskmelon genotypes and the susceptible control 'Santa Cruz Kada' tomato.

\begin{tabular}{|c|c|c|c|c|c|c|}
\hline \multirow{2}{*}{ Treatments } & \multicolumn{2}{|c|}{ Total number of eggs and $\mathrm{J}_{2}$} & \multicolumn{2}{|c|}{ Reproduction factor } & \multicolumn{2}{|c|}{ Reaction $^{(a)}$} \\
\hline & M. javanica & M. incognita & M. javanica & M. incognita & M. javanica & M. incognita \\
\hline AC 29 & $4,031 \mathrm{Aa}^{(\mathrm{b})}$ & $36,400 \mathrm{Ab}$ & 0.80 & 7.28 & $\mathrm{R}$ & $\mathrm{S}$ \\
\hline Vendrantais & $14,125 \mathrm{Ab}$ & $31,750 \mathrm{Ba}$ & 2.82 & 6.35 & $\mathrm{~S}$ & $\mathrm{~S}$ \\
\hline Nantais Oblong & $3,378 \mathrm{Aa}$ & $23,600 \mathrm{Ab}$ & 0.67 & 4.72 & $\mathrm{R}$ & $\mathrm{S}$ \\
\hline PI 124112 & $1,161 \mathrm{Aa}$ & $29,355 \mathrm{Bb}$ & 0.23 & 5.87 & $\mathrm{R}$ & $\mathrm{S}$ \\
\hline WMR-29 & $21,220 \mathrm{Ab}$ & $22,161 \mathrm{Ab}$ & 4.24 & 4.43 & $\mathrm{~S}$ & $\mathrm{~S}$ \\
\hline PMR-45 & $14,300 \mathrm{Ab}$ & $21,500 \mathrm{Ab}$ & 2.86 & 4.30 & $\mathrm{~S}$ & $\mathrm{~S}$ \\
\hline PMR-5 & $3,828 \mathrm{Ab}$ & $15,600 \mathrm{Ab}$ & 0.76 & 3.12 & $\mathrm{R}$ & S \\
\hline PMR-6 & 2,391 Aa & $12,600 \mathrm{Bb}$ & 0.47 & 2.52 & $\mathrm{R}$ & S \\
\hline PI 414723 & $10,174 \mathrm{Ab}$ & $22,900 \mathrm{Ab}$ & 2.03 & 4.58 & $\mathrm{~S}$ & $\mathrm{~S}$ \\
\hline Charentais Fom 1 & $1,307 \mathrm{Aa}$ & $25,450 \mathrm{Bb}$ & 0.26 & 5.08 & $\mathrm{R}$ & $\mathrm{S}$ \\
\hline PI 157082 & $2,414 \mathrm{Aa}$ & $18,500 \mathrm{Bb}$ & 0.48 & 3.70 & $\mathrm{R}$ & $\mathrm{S}$ \\
\hline PI 420145 & $2,553 \mathrm{Aa}$ & $21,950 \mathrm{Bb}$ & 0.51 & 4.39 & $\mathrm{R}$ & $\mathrm{S}$ \\
\hline PI 482398 & $18,368 \mathrm{Ab}$ & $32,550 \mathrm{Bb}$ & 3.67 & 6.51 & $\mathrm{~S}$ & $\mathrm{~S}$ \\
\hline 'Fantasy' & $13,299 \mathrm{Ab}$ & $20,200 \mathrm{Aa}$ & 2.66 & 4.04 & S & S \\
\hline 'Louis' & $15,717 \mathrm{Ab}$ & $46,100 \mathrm{Aa}$ & 3.14 & 9.22 & $\mathrm{~S}$ & S \\
\hline 'Santa Cruz Kada' tomato (c) & 58,457 & 129,057 & 11.70 & 25.80 & $\mathrm{~S}$ & $\mathrm{~S}$ \\
\hline Total mean & $18,861.25$ & & & & & \\
\hline $\mathrm{CV}(\%)$ & 9.63 & & & & & \\
\hline F-test & $4.01 * *$ & & & & & \\
\hline
\end{tabular}


Ito et al. (2014), several mechanisms are involved in plant resistance to Meloidogyne spp., including the phenomena established before, during and after nematode penetration. Resistance in the plant may depend on mechanical, physiological or chemical barriers that impede nematode contact or penetration of tissues by nematodes (Silva et al. 1989).

A number of studies have been carried out with muskmelon, in order to obtain rootstock resistance to Meloidogyne species (Bitencourt \& Silva 2010, Marques et al. 2012, Galatti et al. 2013, LópezGómez \& Verdejo-Lucas 2014). Ito et al. (2014) studied the reaction of cucurbit genotypes that were rootstock candidates for muskmelon cultivation, obtaining four genotypes resistant to $M$. incognita [(CNPH 01-962, CNPH 01-963, 'Gaúcho Redondo' melon and Benincasa hispida (winter melon)] and eight resistant to M. javanica [('Redondo Amarelo' and 'Chilton' melons, 'Charleston Gray' and Citrullus lanatus watermelons, Lagenaria siceraria (bottle gourd), Luffa cylindrica (sponge gourd), Benincasa hispida (winter melon) and Trichosanthes cucumerina (snake gourd)]. However, none of the genotypes assessed showed resistance to both species of root-knot nematodes, corroborating the results obtained here.

Liu et al. (2015) reported a new rootstock from the Cucumis putulatus species resistant to M. incognita and Fusarium wilt, which causes disease in the main cucurbits, including the muskmelon. Anwar \& McKenry (2010) studied the incidence and reproduction of $M$. incognita in genotypes of several plant species (Momordica charantia, Cucumis sativus, Cucurbita argyrosperma, Luffa cylindrica, Citrullus lanatus). They used the reproduction factor to determine the susceptibility and found that $M$. incognita is highly aggressive in cucurbit genotypes, as observed in the present study.

To date, in Brazil, there is no muskmelon genotype with multiple resistance to M. javanica and $M$. incognita. Thus, resistant genetic material can be used in breeding programs aimed at developing cultivars resistant to root-knot nematodes.

The 'AC 29', 'Nantais Oblong', 'PI 124112', 'PMR-5', 'PMR-6', 'Charentais Fom1', 'PI 157082' and 'PI 420145' genotypes were classified as resistant to $M$. javanica. All genotypes were susceptible to M. incognita, among the ones studied here, with no possibility of multiple resistance to both nematode species.

\section{REFERENCES}

ANDRADE, D. E. G. T. et al. Frequência de fungos associados ao colapso do meloeiro e relação com características físicas, químicas e microbiológicas dos solos. Summa Phytopathologica, Botucatu, v. 31, n. 4, p. 327-333, 2005.

ANWAR, S. A.; MCKENRY, M. V. Incidence and reproduction of Meloidogyne incognita on vegetable crop genotypes. Pakistan Journal of Zoology, Faisalabad, v. 42, n. 3, p. 135-141, 2010.

BITENCOURT, N. V.; SILVA, G. S. Reprodução de Meloidogyne enterolobii em olerícolas. Nematologia Brasileira, Piracicaba, v. 34, n. 3, p. 181-183, 2010.

BONETTI, J. I. S.; FERRAZ, S. Modificações do método de Hussey \& Barker para extração de ovos de Meloidogyne exigua em raízes de cafeeiro. Fitopatologia Brasileira, Brasília, DF, v. 6, n. 3, p. 553-558, 1981.

BARBOSA, J. C.; MALDONADO JÚNIOR, W. AgroEstat: sistema para análises estatísticas de ensaios agronômicos. Versão 1.0. Jaboticabal: Unesp, 2010.

EISENBACK, J. D.; SASSER, J.; CARTER, C. Diagnostic characters useful in the identification of the four most common species of root-knot nematodes (Meloidogyne spp.). In: SASSER, J. N.; CARTER, C. C.; BARKER, K. R. An advanced treatise on Meloidogyne. Raleigh: North Carolina State University, 1985. p. 95-112.

FOOD AND AGRICULTURE ORGANIZATION OF THE UNITED NATIONS (FAO). Faostat. 2012. Available at: <http://faostat.fao.org/site/567/DesktopDefault. aspxPageID=567ancor $>$. Acess on: 24 Jul. 2015.

FERRAZ, L. C. C. B. Métodos alternativos de controle de nematoides. Informe Agropecuário, Belo horizonte, v. 16, n. 1 , p. 23-26, 1992.

GALATTI, F. S. et al. Rootstocks resistant to Meloidogyne incognita and compatibility of grafting in net melon. Revista Ceres, Viçosa, v. 60, n. 3, p. 432-436, 2013.

ITO, L. A. et al. Resistência de porta-enxertos de cucurbitáceas a nematoides e compatibilidade da enxertia em melão. Horticultura Brasileira, Brasília, DF, v. 32, n. 3, p. 297-302, 2014.

HUSSEY, R. S.; BARKER, K. R. A comparison of methods of collecting inocula of Meloidogyne spp. including a new technique. Plant Disease Reporter, St. Paul, v. 57, n. 2, p. 1025-1028, 1973.

KARSSEN, G.; MOENS, M. Root-knot nematodes. In: PERRY, R. N.; MOENS, M. (Eds.). Plant nematology. Wallingford: CABI Publishing, 2006. p. 59-90.

INSTITUTO BRASILEIRO DE GEOGRAFIA E ESTATÍSTICA (IBGE). Sistema IBGE de recuperação 
automática. 2013. Available at: <http://www.sidra.ibge. gov.br/bda/tabela/listabl.asp? $\mathrm{c}=1612 \& \mathrm{z}=\mathrm{p} \& \mathrm{o}=20>$. Acess on: 25 Jul. 2015.

LIU, B. et al. A new grafted rootstock against rootknot nematode for cucumber, melon, and watermelon. Agronomy for Sustainable Development, Dijon, v. 35, n. 1, p. 251-259, 2015.

LÓPEZ-GÓMEZ, M.; VERDEJO-LUCAS, S. Penetration and reproduction of root-knot nematodes on cucurbit species. European Journal of Plant Pathology, London, v. 139, n. 4, p. 863-871, 2014.

MARQUES, M. L. S. et al. Hospedabilidade de diferentes espécies de plantas a Meloidogyne enterolobii no Estado do Rio de Janeiro. Nematropica, Sarasota, v. 42, n. 2, p. 304-313, 2012.

OLIVEIRA, C. D. et al. Resistência de pimentas a nematoides de galha e compatibilidade enxerto/ porta-enxerto entre híbridos de pimentão e pimentas. Horticultura Brasileira, Brasília, DF, v. 27, n 4, p. 520526, 2009.

OOSTENBRINK, M. Major characteristics of the relation between nematodes and plants. Mededelingen, Landbouw, v. 66, n. 1, p. 1-46, 1966.

PAIVA, W. O. et al. Melhoramento genético do melão Cantaloupe na Embrapa Agroindústria Tropical. Fortaleza: Embrapa Agroindústria Tropical, 2004.

PEIXOTO, J. R. et al. Avaliação de linhagens, híbridos F1 e cultivares de pimentão quanto à resistência a Meloidogyne spp. Pesquisa Agropecuária Brasileira, Brasília, DF, v. 34, n. 12, p. 2259-2265, 1999.
PERRY, R. N. et al. Root-knot nematodes. Wallingford: CABI, 2009.

PINHEIRO, J. B. et al. Reprodução de Meloidogyne enterolobii em pimentas Capsicum dos grupos Habanero e Murupi. Nematologia Brasileira, Piracicaba, v. 37, n. 4, p. 61-65, 2013.

PINHEIRO, J. B.; AMARO, G. B. Ocorrência e controle de nematoides nas principais espécies cultivadas de cucurbitáceas. Brasília, DF: Embrapa Hortaliças, 2010.

PIRES, M. M. M. et al. Yield of muskmelon subjected to different water management with the use of polypropylene. Horticultura Brasileira, Brasília, DF, v. 31, n. 2, p. 304310, 2013.

RIZZO, A. A. N.; BRAZ, L. T. Características de cultivares de melão rendilhado cultivadas em casa de vegetação. Horticultura Brasileira, Brasília, DF, v. 19, n. 3, p. $237-$ 240, 2001.

SANTOS, A. A. et al. Avaliação de genótipos de melão para resistência à Meloidoginose e ao oídio. Fortaleza: Embrapa Agroindústria Tropical, 1999.

SILVA, G. S. et al. Atração, penetração e desenvolvimento de larvas de Meloidogyne javanica em raízes de Crotalaria spp. Nematologia Brasileira, Piracicaba, v. 13, n. 1, p. 151163, 1989.

TAYLOR, A. L.; NETSCHER, C. An improved technique for preparing perineal patterns of Meloidogyne spp. Nematologia, Leiden, v. 20, n. 2, p. 268-269, 1974. 